\title{
Memories of Beef
}

\author{
Margaret Webb
}

\section{Souvenirs du bifteck}

Sept heures et le vétérinaireveut rentrer chezlui pour y trouver son bifteck et sa fermme mais il a le bras pris jusqu'à l'épaule dans le cul d'une vache...Le "je" poursuit avec le rêve d'un fermier engraissé qui donne naissance à un veau anorexique, mais le tout sort à l'envers.

Ce texte explore la question de la mémoire à travers le réseau de substitutions et de déplacements symboliques qui la tissent. Webb trouve dans la métaphore un rythme quil'empêche de dévier le sens. Elle travaille donc la métonymie, cordon ombilical de la mémoire. Son texte rompt avec la logique de la métaphore, logique qui coupe le lien entre le veau et sa mère, logique qui transforme la génisse en bifteck empaqueté et congélé. Au lieu de répéter cette logique et de transformer la génisse encore une fois - cette fois en un signifiant dans un poème - le texte souligne la contiguïté des termes, les rapports intimes qui retracent le cheminement de la mémoire.

"The female sex organs are the blind spot."

- Jane Gallop

"I think where I am not, therefore I am where I think not."

- Jacques Lacan

1.

seven o' clock and the vet wants to go

home to his steak and his wife but

he's got his arm to his shoulder up the ass

of a cow yanking the calf out by its hind legs already 100

pounds too big to walk even jerkily the way new calves do and blind

steam from the manure

steam from the afterbirth 
steam from the uterus that's come out with the calf

2.

in Montreal, where memory is occurring, metaphor leaps over whole decades of my life with slant regard to metonymy, what simmers beneath the surface and connects me

oh, I buy The Gazette, get groceries, go to the bank but what I'm saying is

I don't go out in the city

\section{3.}

when I'm 12 and watching this cow having been fed to make beef too fat to have calves its calf too big to stand my father says go to the house already an hour ago

the cow never getting up the next day becomes string-wrapped packages in our freezer

in the summer it's my job to wash the grey liquid oozing from the blind calf's eyes to keep flies off the blind calf's eyes

4.

I don't know why I'm having this memory of beef I stopped eating it months ago maybe I'm anemic; I sleep too much last night I went to bed at 11 woke up 
at 3 went back to sleep

at 6 got up at 10

face of the clock ticking a kind of metonymy

relating what passes

for days, lying in

the heat watching flies

mate on the ceiling

too lazy to get up

to close the screen

you think I'm depressed

on account of the sleep

on account of not going out in the city

on account of watching the flies

my father scraped the uterus up with a shovel

not that I want a connection

between that uterus and my

not going out in the city

I'm not trying to make one

I'm trying to make a poem

what the flies are doing here I don't know

5.

I am writing the poem because I believe a poem can

a) soak up the excess of metaphor

b) supply memory with its own metonymy

c) release me from trying to bend not just lines but the whole of my being into its absurd connections and

d) give me my life back

when I think in metaphor there is a certain rhythm which does not let me change 
direction seemingly changes

of its own volition, leaping

over logic to create another kind

of logic which makes street

corners hazardous keeping

me indoors and dreaming

a fatted farmer birthing an anorexic

calf and a fence I'm trying to jump over

which is too

high or a man and a woman who have invited me to dinner when I would still go out in the city but they discover that I

have these memoies of beef and they pretend not to have invited me to dinner, saying there is no roast in the oven

and the table is set for their inlaws who I wouldn't like

any more than the beef

6.

it was after dinner that I dreamt

the fatted farmer giving birth to the anorexic

calf though it came out

the other way around

there might be a connection

in the breech

if you don't fill it in

with connections

it was Freud who said you need

the blind spots to see

how the flies squeezed black body to black body

over the face of the blind calf

to drink the liquid from the blind calf's eyes

and the blind calf not having a mother 
7.

that relation being another kind of metonymy the umbilical cord of metonymy

that is cut

turning the mother into a free-floating signifier or three-quarter-inch steaks

in the deep freeze

metaphor breathing cold or hot in its searching and taking schizophrenic leaps on young calf's legs

8.

in the city that I don't go out in there's a bar that I don't go into riding my bicycle one day (in a time I used to go out) it caught my attention that bar being a lesbian bar I lost sight of the straightness of the road I hit the curb I flew forward and jammed my pelvis when I hit the curb

it wasn't that my uterus had to be scraped up off the street only that it felt that way

9.

my other cow memory is of selling that calf at the end of the summer I got $\$ 100$ for wiping the goo off its face for three months I got new clothes for school in the fall it went to the slaughterhouse 